\title{
Ability and Workload on Organizational Performance through Organizational Commitments: Case Study in Employee Directorate Supervisors in Retirement Funds and Employment Management Agencies
}

\section{Dikdik Kurnia}

Universitas Krisnadwipayana

Po Box 7774 / Jat Cm Jakarta, Indonesia

Email:d.kurnia@gmail.com

Indonesia

Suharto

Universitas Krisnadwipayana

Po Box 7774 / Jat Cm Jakarta, Indonesia

Email: suharto@unkris.ac.id

Indonesia

\section{Iwan Kurniawan Subagja}

Universitas Krisnadwipayana

Po Box 7774 / Jat Cm Jakarta, Indonesia

Email: iksubagja@gmail.com

Indonesia

\section{ABSTRACT}

This study aims to determine the effect of ability and workload on the organizational performance simultaneously, determine the effect of the ability to organizational performance partially, determine the effect of workload on the organizational performance partially, determine the effect of organizational commitment on organizational performance partially, determine the effect of ability on performance organization through organizational commitment and determine the effect of workload on organizational performance through organizational commitment. The study was conducted in the supervision Directorate of the Pension Fund and the Social Security Agency Employment FSA. Sampling using saturated samples involving 36 employees in all parts of the organization. Analysis of data using path analysis.

Based on data analysis found that the variable ability and workload impact on organizational performance simultaneously. Variable's ability affects organizational performance partially. Variable workload affects organizational performance partially. Organizational commitment variables effect on organizational performance partially. Organizational commitment to organizational performance can provide an improved impact between ability and workload on organizational performance.

Keywords: ability, workload, organizational commitment, organizational performance

\section{Introduction}

The organization's performance can be measured by monitoring and reporting programs, and pay attention to objectives achieved. Performance is measured based on the activity on use within the program is run, products and services produced. Organizational performance should not be measured only in terms of financial concepts but also of non-financial. Performance can be measured by productivity, quality, consistency and so on. On the other hand, measure organizational performance outcomes, behavioral and normative level, education and concepts generated including management development (Richard, 2010).

One of the factors that affect the performance of the organization is the ability of employees, workload and organizational commitment. According to Thoha (2010) capability is one element in the maturity related to the knowledge or skills that can be gained from education, training, and experience. Indeed, the ability of someone devoted only a fraction of the potential contained in itself. In this case, the need for a workload to move so more work performance can be seen and felt. 
Demonstrate the potential of the ability to perform the task or job. That might be exploited or maybe not. The ability is closely related to physical and mental abilities that people may have to carry out the work and not wanting to do (Gibson, 2006:104). The ability of a person can be measured by the level of skills and knowledge in performing the tasks assigned. With existing skills than trying to improve the quality and quantity of his work. Ability is the ability of individuals to carry out various tasks in a particular job. The whole ability of an individual is essentially composed of two sets of factors: intellectual ability and physical ability.

The workload also affects the performance of the organization. According to Komaruddin (1996:235), Workload analysis is a process to set the number of hours people are used or needed to complete a job within a certain time, or in other words workload analysis aims to determine how the number of personnel and the amount of responsibility or workload right delegated to an officer.

According to Simamora(2008:57), Workload analysis is to identify a good number of employees and employee qualifications necessary to achieve organizational goals. According to the Menpan (1997), understanding the workload is a set or some activities that must be completed by an incumbent organizational unit or within a certain period. Workload measurement is defined as a technique to obtaining information about the efficiency and effectiveness of a unit of the organization, or the incumbent are carried out systematically by using job analysis techniques, workload analysis techniques or other management techniques. Further stated also, that measurement is one of the workload management techniques to obtain information office, through the process of research and assessment conducted the analysis.

Organizational commitment can also affect the performance of the organization. According to Robbins and Judge (2008:100) organizational commitment is a condition in which an employee favoring certain organizations as well as the goals and desires to retain membership in the organization. Thus, a high job involvement means favoring certain work of an individual, while a high organizational commitment means favoring organizations that recruit such individuals.

Meanwhile, according to Moorhead and Griffin (2013:73) organizational commitment is an attitude that reflects the extent to which an individual knows and adheres to the organization. An individual who has committed is likely to see himself as a true member of the organization. Meanwhile, according to Kreitner and Kinicki (2014:165) that reflects the organization's commitment to recognizing the degree to which someone tied to an organization and its goals.

It can be concluded that organizational commitment is a psychological state of individuals associated with faith, trust and a strong reception to the goals and values of the organization, a strong willingness to work for the organization and the degree to which it still wants to be a member of the organization.

\section{Literature Review}

\section{Organizational Performance}

According to Richard et al (2010) the performance of the organization is generated by an organization that includes the results of that financial performance such as profit, as measured by return on assets, return on investment and so on, the performance of markets such as the expansion of market share, and sales. Besides the return of shareholders, a return of shareholders and increase the economy of shareholders.

In some areas of the organization's performance can also be measured by other things such as strategic planning, operations, finance, legal and organizational development. In developing the institution or organization is a necessity to survive in the competitive world climate.

The purpose of productivity associated with the development of that organization (Shrestha,1997). Small organizations that have a desire to continue to grow and become large. The growing organization to the development itself.

\section{Ability}

According to Thoha (2010) capability is one element in the maturity related to the knowledge or skills that can be gained from education, training, and experience. Indeed, the ability of someone devoted only a fraction of the potential contained in itself. In this case, the need for motivation to move so more work performance can be seen and 
felt. Demonstrate the potential of the ability to perform the task or job. That might be exploited or maybe not. The ability is closely related to physical and mental abilities that people may have to carry out the work and not wanting to do (Gibson, 2006:104).

Based on the above description that if you want to achieve maximum results an employee must work in earnest along with all the capabilities supported by the existing infrastructure. If an employee working half-heartedly then the work produced is not as much as expected. This means that the ability can be measured by the level of skills and knowledge in performing the tasks assigned. With existing skills then employee trying to improve the quality and quantity of his work.

According to Robbins (2010:52) is the ability of an individual's ability to perform tasks in the job. Soelaiman (2007:112) is the ability of nature congenital or learned that allows a person to get the job done, either mentally or physically. Employees in an organization, albeit motivated by good, but never all can work well. Ability and skills to play a major role in behavior and individual achievements. Skills are skills relations with the task that is owned and used by someone right time.

\section{Workload}

According to Komaruddin (1996:235), Workload analysis is a process to set the number of hours people are used or needed to complete a job within a certain time, or in other words workload analysis aims to determine how the number of personnel and the amount of responsibility or workload right delegated to an officer.

According to Simamora (2008:57) workload analysis is to identify a good number of employees and employee qualifications necessary to achieve organizational goals. According to the Menpan (1997), understanding the workload is a set or several activities that must be completed by an incumbent organizational unit or within a certain period. Workload measurement is defined as a technique to obtaining information about the efficiency and effectiveness of a unit of the organization, or the incumbent are carried out systematically by using job analysis techniques, workload analysis techniques or other management techniques. Further stated also, that measurement is one of the workload management techniques to obtain information office, through the process of research and assessment conducted the analysis.

According to Heizer and Render (1996: 98), Labor standards is the amount of time it takes the average labor, to do special work activities under normal working conditions, or in other words, labor standards can be used to set the number of personnel, in order to be able to produce the expected production company. Further said that to determine labor standards can be done in four ways, based on experience, the assessment time, a standard time before the determination, and sampling work. Labor productivity can be described in the efficient use of labor. Where the labor force will be used efficiently if the amount of labor that is balanced with the workload.

Workload analysis is a process to set the number of hours people are used or needed to complete a job within a certain time, or in other words workload analysis aims to determine how the number of personnel and the amount of responsibility or workload right delegated to an officer, Workload analysis aims to determine how the number of employees needed to complete a job and how much responsibility or workload can be delegated to an employee, or it can be noted that the workload analysis is the process to set the number of hours people are used or needed to complete the workload within a certain time.

\section{Organizational Commitment}

According to Robbins and Judge (2008:100) organizational commitment is a condition in which an employee favoring certain organizations as well as the goals and desires to retain membership in the organization. Thus, a high job involvement means favoring certain work of an individual, while a high organizational commitment means favoring organizations that recruit such individuals.

Meanwhile, according to Moorhead and Griffin (2013:73) organizational commitment is an attitude that reflects the extent to which an individual knows and adheres to the organization. An individual who has committed is likely to see himself as a true member of the organization. Meanwhile, according to Kreitner and Kinicki (2015:165) that reflects the organization's commitment to recognizing the degree to which someone tied to an organization and its goals. 
It can be concluded that organizational commitment is a psychological state of individuals associated with faith, trust and a strong reception to the goals and values of the organization, a strong willingness to work for the organization and the degree to which it still wants to be a member of the organization. Organizational commitment is the attitude of employees who are interested in goals, values and objectives of the organization shown by their acceptance of individuals on the values and goals of the organization and have a desire to affiliate with the organization and a willingness to work hard for the organization to make people feel at home and still want to stay in the organization for the sake of achievement of objectives and survival of the organization.

\section{Research Methods}

\section{Research Design}

This research uses an explanatory analysis approach. This means that each of the variables presented in the hypothesis will be observed by testing the causal relationship of independent variables on the dependent variable. Relationships between variables can be described in terms of the path analysis diagram as follows:

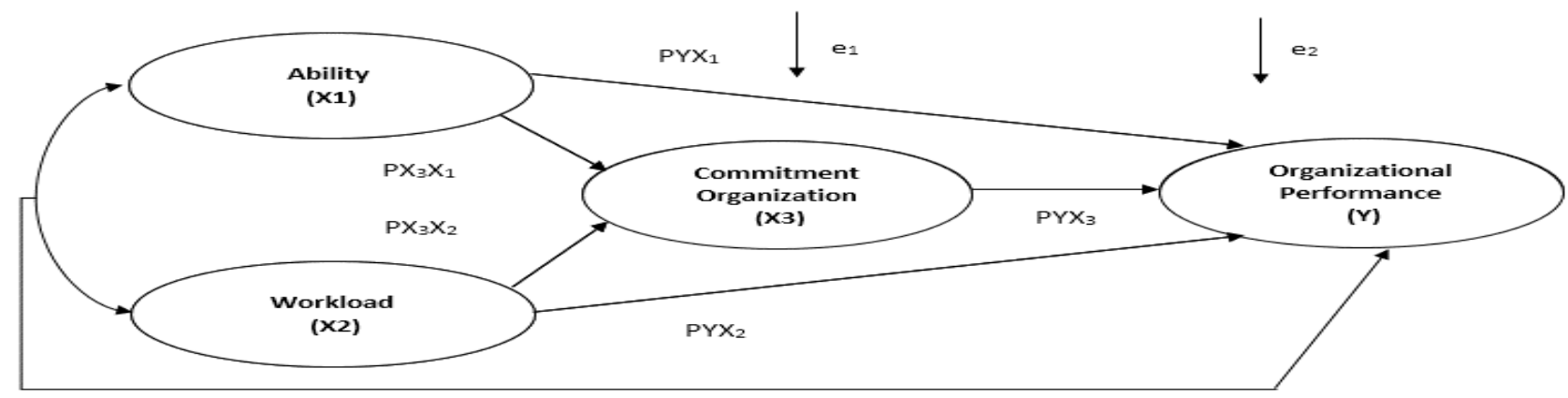

Figure 1. Framework Research

\section{Object of Research}

The study was conducted in Supervision Directorate of the Pension Fund and the Social Security Agency Employment FSA.

\section{Population and Sample Research}

The population is a generalization region consisting of the objects/subjects that have a certain quantity and characteristics defined by the researchers to learn and then drawn conclusions (Sugiyono,2014). Samples were towing the majority of the population to represent the entire population, (Surakhmad, 2001).

The population used in this study is the number of employees the company is as many as 36 people. The number of samples taken entirely from the population. This sampling method saturated samples.

\section{Research Result}

\section{Influence of Ability and Workload on Organizational Performance}

The linear analysis model can be based on calculations using the SPSS program as follows.

Table 1. Results of the analysis of the first equation

Coefficients

\begin{tabular}{|c|c|c|c|c|c|}
\hline \multirow[b]{2}{*}{ Model } & \multicolumn{2}{|c|}{$\begin{array}{l}\text { Unstandardized } \\
\text { Coefficients }\end{array}$} & \multirow{2}{*}{$\frac{\text { Standardized Coefficient }}{\text { beta }}$} & \multirow[b]{2}{*}{$\mathrm{t}$} & \multirow[b]{2}{*}{ Sig. } \\
\hline & B & Std. Error & & & \\
\hline $1 \quad$ (Constant) & 15.658 & 5,037 & & 3,109 &, 004 \\
\hline ABILITY &, 713 &, 219 & 400 & 3.254 &, 003 \\
\hline WORKLOAD &, 579 &, 128 & 555 & 4.514 &, 000 \\
\hline
\end{tabular}

a. Dependent Variable: PERFORMANCE

Based on the tables above, the simultaneous structural equations can be described as follows; 
Table 2. Calculate the $\mathbf{F}$ value equations simultaneously ANOVA

\begin{tabular}{|c|c|c|c|c|c|}
\hline Model & Sum of Squares & $\mathrm{df}$ & mean Square & $\mathrm{F}$ & Sig. \\
\hline $1 \quad$ Regression & 626.176 & 2 & 313.088 & 16.723 &, $000 b$ \\
\hline Residual & 617.824 & 33 & 18.722 & & \\
\hline Total & 1244.000 & 35 & & & \\
\hline
\end{tabular}

a. Dependent Variable: PERFORMANCE

b. Predictors: (Constant), ABILITY, WORKLOAD

Based on the above table it is known that the value $\mathrm{f}$ calculated at 16.723 and significance of 0.00 . This value is less than 0.05. This means that the variable ability and workload impact on organizational performance simultaneously. The magnitude of the effect of the independent variable on the dependent variable can be seen from the following values of $r$ squared.

\section{Table 3. Values r squared regression model first}

Model Summary

\begin{tabular}{|l|r|r|r|r|r|}
\hline Model & $\mathrm{R}$ & $\mathrm{R}$ Square & $\begin{array}{c}\text { Adjusted } \mathrm{R} \\
\text { Square }\end{array}$ & $\begin{array}{c}\text { Std. Error of the } \\
\text { Estimate }\end{array}$ & Durbin-Watson \\
\hline 1 &, $709 \mathrm{a}$ &, 503 &, 473 & 4.32689 & 1,243 \\
\hline
\end{tabular}

a. Predictors: (Constant), ABILITY, WORKLOAD

b. Dependent Variable: PERFORMANCE

Based on the above table it is known that the value of $\mathrm{r}$ squared of 50.3\% meaning that the variable ability and workload impact on organizational performance of $50.3 \%$ while the rest influenced by other variables that are not incorporated into the model equations.

\section{Influence Analysis of Ability on Organizational Performance}

The analysis results ability on organizational performance can be seen in the following table.

Table 4. Results of the analysis of the second regression equation

Coefficients

\begin{tabular}{|c|c|c|c|c|c|}
\hline \multirow[b]{2}{*}{ Model } & \multicolumn{2}{|c|}{ Unstandardized Coefficients } & \multirow{2}{*}{$\begin{array}{c}\text { Standardized Coefficients } \\
\text { beta } \\
\end{array}$} & \multirow[b]{2}{*}{$\mathrm{t}$} & \multirow[b]{2}{*}{ Sig. } \\
\hline & $\mathrm{B}$ & Std. Error & & & \\
\hline $1 \quad$ (Constant) & 26.573 & 5.536 & & 4,800 &, 000 \\
\hline ABILITY &, 790 & 274 & 444 & 2,885 &, 007 \\
\hline
\end{tabular}

a. Dependent Variable: PERFORMANCE

Structural equation of the above data can be seen as follows: $\mathrm{Y}=0.444 \mathrm{X} 1$

Based on the chart above analysis it is known that the coefficient of 0.444 capabilities. $T$ value of 2.885 . The significant value of 0.00 . The significance value smaller than 0.05 . This means that variables affectability on organizational performance partially. The amount of influence ability on organizational performance can be seen in the following table.

Table 5. Values $r$ squared second equation

Model Summary

\begin{tabular}{|l|r|r|r|r|}
\hline Model & $\mathrm{R}$ & R Square & Adjusted R Square & $\begin{array}{c}\text { Std. Error of the } \\
\text { Estimate }\end{array}$ \\
\hline 1 &, $444 \mathrm{a}$ &, 197 &, 173 & 5.42138 \\
\hline
\end{tabular}

a. Predictors: (Constant), ABILITY

Based on the above table it can be seen $r$ squared value of 0.197 . This means that the effect of ability on organizational performance of $19.7 \%$ and the rest influenced by other variables not included in the model equations. 


\section{Analysis of Effect Workload on Organizational Performance}

Effect workload on organizational performance can be partially seen in the following table

Table 6. Results of the analysis of the third regression equation

Coefficients

\begin{tabular}{|c|c|c|c|c|c|}
\hline \multirow[b]{2}{*}{ Model } & \multicolumn{2}{|c|}{ Unstandardized Coefficients } & \multirow{2}{*}{$\frac{\text { Standardized Coefficients }}{\text { beta }}$} & \multirow[b]{2}{*}{$\mathrm{t}$} & \multirow[b]{2}{*}{ Sig. } \\
\hline & \begin{tabular}{|c|}
$\mathrm{B}$ \\
\end{tabular} & Std. Error & & & \\
\hline $1 \quad$ (Constant) & 29.189 & 3,218 & & 9.070 &, 000 \\
\hline WORKLOAD &, 611 &, 145 & 587 & 4,223 &, 000 \\
\hline
\end{tabular}

a. Dependent Variable: PERFORMANCE

Structural equation of the above data can be seen as follows: $\mathrm{Y}=0.587 \mathrm{X} 2$

Based on the chart above analysis it is known that the working load coefficient of 0.587 . $\mathrm{T}$ value of 4,223. The significant value of 0.00 . The significance value smaller than 0.05 . This means that the variable workload affects the performance of an organization partially. The workload amount of influence on organizational performance can be seen in the following table.

Table 7. The third equation $r$ squared

Model Summary

\begin{tabular}{|l|r|r|r|r|}
\hline Model & $\mathrm{R}$ & \multicolumn{1}{|c|}{ R Square } & Adjusted R Square & \multicolumn{1}{c|}{$\begin{array}{c}\text { Std. Error of the } \\
\text { Estimate }\end{array}$} \\
\hline 1 &, $587 \mathrm{a}$ &, 344 &, 325 & 4.89914 \\
\hline
\end{tabular}

a. Predictors: (Constant), WORKLOAD

Based on the above table it can be seen $r$ squared value of 0.325 . This means that the effect of variable workload on the performance of the organization and the remaining $32.5 \%$ is influenced by other variables that are not incorporated into the model equations.

\section{Influence Analysis of Organizational Commitment to Organizational Performance}

The analysis results in organizational commitment on organizational performance of partial work can be seen in the following table.

Table 8. Results of the fourth regression equation analysis Coefficients

\begin{tabular}{|c|c|c|c|c|c|}
\hline \multirow[b]{2}{*}{ Model } & \multicolumn{2}{|c|}{ Unstandardized Coefficients } & \multirow{2}{*}{$\frac{\text { Standardized Coefficients }}{\text { beta }}$} & \multirow[b]{2}{*}{$\mathrm{t}$} & \multirow[b]{2}{*}{ Sig. } \\
\hline & $\mathrm{B}$ & Std. Error & & & \\
\hline $\begin{array}{ll}1 & \text { (Constant) } \\
& \text { COMMITMENT }\end{array}$ & $\begin{array}{r}6.859 \\
, 849\end{array}$ & $\begin{array}{r}4.229 \\
, 100\end{array}$ & 824 & $\begin{array}{l}1.622 \\
8.466\end{array}$ & $\begin{array}{l}, 114 \\
, 000\end{array}$ \\
\hline
\end{tabular}

a. Dependent Variable: PERFORMANCE

Structural equation of the above data can be seen as follows: $\mathrm{Y}=0.824 \mathrm{X} 3$

Based on the chart above analysis it is known that the coefficient of organizational commitment at 0.824 . $\mathrm{T}$ value of 8.466. The significant value of 0.00 . The significance value smaller than 0.05 . This means that the organizational commitment variables affect the performance of an organization partially. The magnitude of the effect of organizational commitment on organizational performance can be seen in the following table.

Table 9. Values $r$ squared fourth equation

Model Summary

\begin{tabular}{|l|r|r|r|r|}
\hline Model & R & R Square & Adjusted R Square & \multicolumn{1}{c|}{$\begin{array}{c}\text { Std. Error of the } \\
\text { Estimate }\end{array}$} \\
\hline 1 &, $566 \mathrm{a}$ &, 321 &, 301 & 4.83499 \\
\hline
\end{tabular}

a. Predictors: (Constant), ABILITY

Based on the above table it can be seen $r$ squared value of 0.321 . This means that the effect of variable organizational commitment to organizational performance and the remaining $32.1 \%$ is influenced by other variables that are not incorporated into the model equations. 


\section{Influence Analysis of Ability on Organizational Performance through Organizational Commitment}

Based on the partial path analysis above, it can be described as follows. The analysis is an analysis in line with the structure of this sub-image.

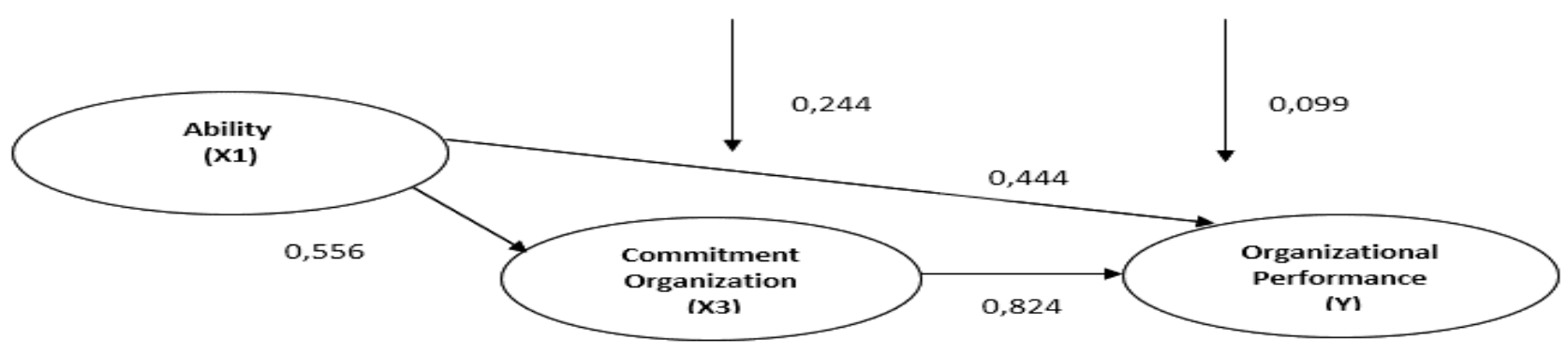

Figure 2. Analysis of the influence lines X1 to Y via X3

The coefficient influences the ability to organizational commitment can be seen in the following table

Table 10. Effect of the ability to organizational commitment

Coefficients

\begin{tabular}{|c|c|c|c|c|c|}
\hline \multirow[b]{2}{*}{ Model } & \multicolumn{2}{|c|}{ Unstandardized Coefficients } & \multirow{2}{*}{$\frac{\text { Standardized Coefficients }}{\text { beta }}$} & \multirow[b]{2}{*}{$\mathrm{t}$} & \multirow[b]{2}{*}{ Sig. } \\
\hline & \begin{tabular}{|c|}
$\mathrm{B}$ \\
\end{tabular} & Std. Error & & & \\
\hline 1 (Constant) & $\begin{array}{r}22.257 \\
070\end{array}$ & $\begin{array}{r}4,937 \\
244\end{array}$ & 566 & 4.508 &, 000 \\
\hline
\end{tabular}

a. Dependent Variable: COMMITMENT

Based on the picture above can be seen that the effect of the ability to organizational performance is 0.444 . Ability to influence organizational performance through organizational commitment is $0.566 \times 0.824=0.466$. In this case, the indirect effect is greater than the direct effect so that it can be said that the work organization commitment variable as an intervening variable.

\section{Workload Analysis of Effect on Organizational Performance Through Organizational Commitment}

Based on the partial path analysis above, it can be described as follows. The analysis is an analysis in line with the structure of this sub-image.

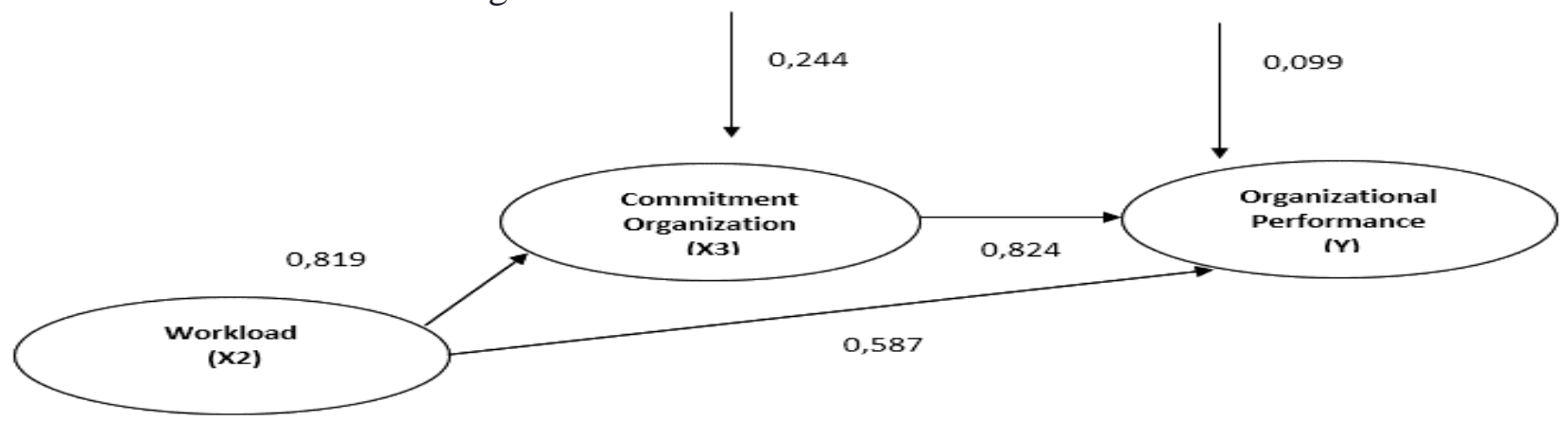

Figure 3. Analysis of the influence lines X2 to Y via X3

The coefficient of ability to organizational commitment can be seen in the following table.

Table 11. Workload coefficient influence on organizational commitment Coefficients

\begin{tabular}{|l|r|r|r|r|r|}
\hline \multirow{2}{*}{ Model } & \multicolumn{2}{|c|}{ Unstandardized Coefficients } & Standardized Coefficients & & \\
\cline { 2 - 4 } & \multicolumn{1}{|c|}{ B } & Std. Error & beta & \multicolumn{1}{c|}{ Sig. } \\
\hline
\end{tabular}

a. Dependent Variable: COMMITMENT 
Based on the picture above it can be seen that the direct effect workload on the performance of the organization is 0.587 . While the influence of the workload on the performance of the organization through the commitment of work organization is $0.819 \times 0.824=0.674$. In this case smaller than the direct influence indirect influence so that it can be said that the work organization commitment variable as an intervening variable.

\section{Conclusions and Suggestions}

\section{Conclusion}

Variable ability and workload impact on organizational performance simultaneously. F value calculated at 16.723 and the significance of 0.00 . This value is less than 0.05 . R squared value of $50.3 \%$ meaning that the variable ability and workload impact on organizational performance of $50.3 \%$ while the rest influenced by other variables that are not incorporated into the model equations.

Variables affect the performance of the organization's ability partially. T value of 2.885 . The significant value of 0.00 . The significance value smaller than 0.05 . R squared value of 0.197 . This means that the effect of variables on the performance capability of $19.7 \%$ and the rest influenced by other variables not included in the model equations.

Variable workload affects the performance of an organization partially. T value of 4,223. The significant value of 0.00 . The significance value smaller than 0.05 . $\mathrm{R}$ squared value of 0.325 . This means that the effect of variable workload on the performance of the organization and the remaining $32.5 \%$ is influenced by other variables that are not incorporated into the model equations.

Organizational commitment variables affect the performance of an organization partially. T value of 8.466. The significant value of 0.00 . The significance value smaller than 0.05 . $\mathrm{R}$ squared value of 0.321 . This means that the effect of variable organizational commitment to organizational performance and the remaining $32.1 \%$ is influenced by other variables that are not incorporated into the model equations.

Influence the ability to organizational performance is 0.444. Ability to influence performance through organizational commitment is $0.566 \times 0.824=0.466$. In this case, the indirect effect is greater than the direct effect so that it can be said that the organization's commitment variable as an intervening variable.

The direct effect of workload on the performance of the organization is 0.587 . While the influence of the workload on the performance of the organization through the commitment of the organization is $0.819 \times 0.824=$ 0.674. In this case smaller than the direct influence indirect influence so that it can be said that organization commitment variable as an intervening variable.

\section{Suggestion}

Ability is one element in the maturity related to the knowledge or skills that can be gained from education, training, and experience. Enhanced capabilities through increased ability technic, are human capabilities, and the ability of the concept.

The workload is a set or several activities that must be completed by an incumbent organizational unit or within a certain period. Workload measurement is defined as a technique to obtaining information about the efficiency and effectiveness of a unit of the organization, or the incumbent is carried out systematically by using job analysis techniques, workload analysis techniques or other management techniques. To improve the performance of the organization, the workload increased through an increase in duty aspects, aspects of one, and aspects of the condition.

Commitment is a condition in which an employee favoring certain organizations as well as the goals and desires to retain membership in the organization. The commitment is enhanced with affective commitment, continuous commitment, and normative commitment.

\section{References}

Ahmad, Komarudin. (1996). Dasar-dasar Manajemen Investasi. Jakarta : Rineka. Cipta.

Daft, Richard L. (2010). Manajemen. Edisi Kelima Jilid Satu. Jakarta : Erlangga. 
Gibson, James L., John M.Ivancevich, and James H.Donnelly, (2006). Organization Behavior-Structure-Process, $7^{\text {th }}$ Edition, Erwin Homewood, Boston.

Heizer, Jay dan Barry Render, (1996). Operations Management 5th ed, New Jersey: Prentice Hall, inc.

Kreitner dan Kinicki, (2015), Organizational Behavior. 8 th Edition. Boston: McGraw-Hill.

Menpan. (1997). Definisi Beban Kerja. http://www.bkn.go.id. (diakses pada tanggal 6 Mei 2018)

Moorhead, Gregory dan Ricky W. Griffin. (2013). Perilaku Organisasi. Jakarta: Salemba Empat.

P. Robbins, Stephen; Coulter, Mary, (2010). Manajemen, Edisi 10, Jilid 1 dan 2, Penerbit Erlangga. Jakarta.

Robbins P. Stephen and Judge A.Timothy (2008) Organisasi Behaviour, Jakarta: Pearson Education, Inc

Shrestha, Taliziduhu, (1997). Metodologi Ilmu Pemerintahan. Jakarta: Rineka Cipta.

Simamora. (2008). Manajemen Sumber Daya Manusia.Yogyakarta : Adi Citra Karya Nusa.

Soelaiman. (2007). Manajemen Kinerja ; Langkah Efektif untuk Membangun, Mengendalikan dan Evaluasi Kerja, Cetakan Kedua, PT. Intermedia Personalia Utama. Jakarta.

Sugiyono. (2014). Metode Penelitian Kuantitatif, Kualitatif, dan Kombinasi (Mixed Methods). Bandung: Alfabeta Thoha, Miftah, (2010). Kepemimpinan Dalam Manajemen. Rajawali Pers. Jakarta.

Winarno Surakhmad. (2001). Pengantar Penelitian Ilmiah Dasar Metode Teknik. Bandung: Tarsito 